\title{
Management of financial risks in the security system of enterprise development: economic and legal aspects
}

\author{
Viktoriya Prokhorova ${ }^{1 *}$, Svitlana Mushnykova ${ }^{2}$, Oleksiy Bytiak $^{3}$, and Krystyna \\ Slastianykova ${ }^{3}$ \\ ${ }^{1}$ Ukrainian Engineering and Pedagogical Academy, Department of Economics and Organization of \\ the Activity of Business Entities, 61003, 16 Universitetskaya st., Kharkiv, Ukraine \\ ${ }^{2}$ National Metallurgical Academy of Ukraine, Department of Finance, 4 Gagarin ave., 49005 Dnipro, \\ Ukraine \\ ${ }^{3}$ Yaroslav Mudryi National Law University, Department of Economic Law, Pushkinskaya str., 77, \\ 61024 Kharkiv, Ukraine
}

\begin{abstract}
The state of market relations which is determined by the high level of competition, instability and environmental variability, requires from each subject of the weighted actions to manage the safe development. The risks accompanying the activities of each enterprise are the components of its management. The necessity of considering financial risks as a generalizing factor of the security system of enterprise development is substantiated. The research proposes a methodological approach within the framework of economic and legal aspects to the management of financial risks in the security system of the enterprise development, with the definition of the main theoretical positions, namely: goals, objectives, principles, legal entities and methods of managing financial risks in accordance with the stage of the life cycle enterprises The necessity of improvement of legal support of legal relations with the enterprise in the system of security of enterprise development is determined.
\end{abstract}

\section{Introduction}

The current state of market relations is determined by the high level of competition, instability and volatility of the environment. These are also the main barriers, and in some cases, and stimulants on the way to the development of industrial enterprises, which can only be overcome if the development of a system for development security within an enterprise management system is created. One of the areas of the development security system is risk management at the enterprise.

*Corresponding author: vkprohkorova@gmail.com 
The activity of any entity is associated with the emergence of a large number of risks and threats to their implementation throughout its life cycle. Over the past decades, many scholars and practitioners have focused on defining the concept of risk, evaluating its occurrence and managing it using various methods and techniques $[1,9,11,12]$. Based on the experience gained, it was concluded that risks are not a sentence but an existing reality. In general, the risk can be represented as the probability of occurrence of an event and / or a certain result. Moreover, if the risks were predictable (expected) and timely measures were taken to avoid or minimize, the result of the activity can be extremely positive.

On the other hand, the security of enterprise development should also take into account the legal support of the subjects of relations in the management of risks. However, legal support has not received enough attention at any level of the national economy. Although, according to Article 42 of the Commercial Code of Ukraine, entrepreneurship is an independent, initiative, systematic, at its own risk, economic activity carried out by economic entities (entrepreneurs) in order to achieve economic and social results and profit [16], there is no integrated regulatory framework for risk management regulation. All these conditioned the relevance of this study.

\section{Main body}

One of the main groups of risks associated with the economic activity of industrial enterprises are financial risks, which, in they turn, can be considered as a generalization indicator. They accompany enterprises at all stages of the production and financial cycles, and reflect the positive or negative impact of existing risks on it. Moreover, depending on the stage of the life cycle, starting from the stage of entering the market, passing the stage of growth or expansion of activity, maturity, saturation, even before the exit from the market, there may be various threats and risks. Therefore, it should be considered necessary to determine the methodological approach to managing financial risks in the system of security of enterprises development, taking into account both the economic and legal aspects of enterprises.

\subsection{Methodological Approach to Financial Risk Management in the Enterprise Security System}

Each industrial enterprise wants to develop with a certain level of protection against possible threats and risks accompanying their activities at every stage of the life cycle, not only in economic activity, but also in legal relationships with different actors. Therefore, according to the authors, the main objective of managing financial risks in the system of enterprise development security in both the economic and legal aspects is to achieve a safe development of an enterprise with the optimal level of financial risk (Fig.1).

Achievement of the set goal is possible only under conditions of thorough and reliable analysis of existing and/or possible threats and risks of both internal and external origin, assessment of the current status of the results of the enterprise and forecasting them with the possibility of preventing possible future risks.

The management of financial risks within the framework of the security system of enterprise development should be based on a set of economic and legal principles. Within the framework of the imperative principles [16]:

1) protection by the state of all subjects of ownership and management;

2) ensuring equal conditions for their rights and guarantees of equality before the law;

3) independence of the development of business entities action program - in the management of financial risks within the security system of the enterprise must adhere to the following basic principles of economic activity, namely: 
1) awareness, manageability, risk management efficiency, which involve taking risks only those that are subject to neutralization, and the costs of their neutralization should not exceed the sum of possible financial losses on it, even with the highest degree of likelihood of occurrence of a risk case;

2) comparison of the level of risks with the level of profitability of financial transactions and the level of financial capacity of the enterprise;

3 ) independence of management of individual risks of the enterprise, that is, financial losses do not depend on each other on individual risks.

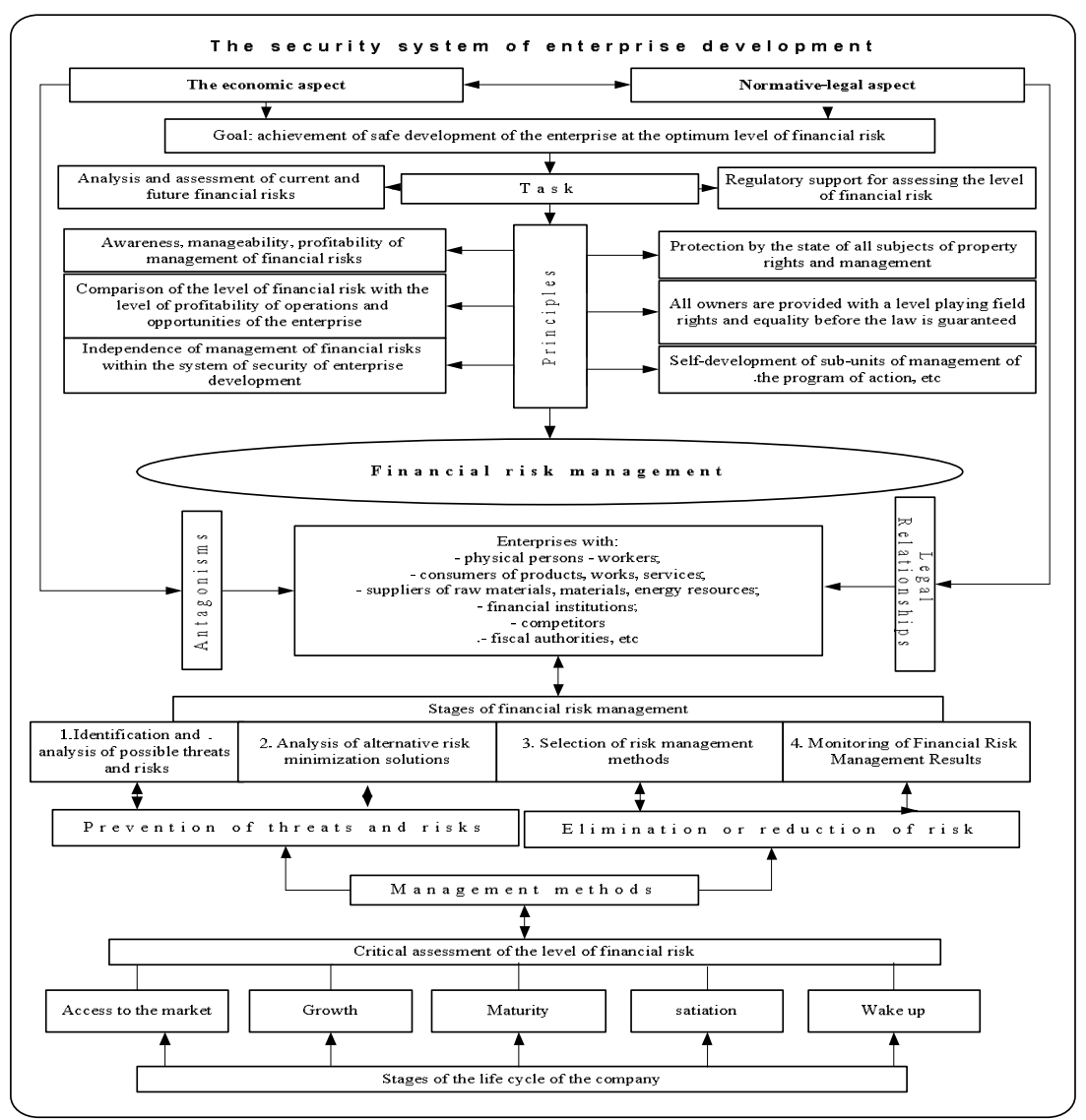

Fig 1. Methodological approach to managing financial risks in the enterprise security system

Adhering to the proposed principles for financial risk management, the company forms legal relationships with various entities with pronounced antagonisms between them, which, in turn, affect the emergence and/or aggravation of existing threats and risks in the relationship. However, today in Ukraine, the state authorities, only legal documents that partially regulate the production risks of certain sectors of the national economy (customs, building legislation, etc.) are developed, and the risks of the financial sector, which is mediating for enterprises (insurance activities [2] , banking [3], securities market activity, audit), which exacerbates the contradictions between market participants as a result of the unilateral protection of their activities, thus restricting the rights of economic entities. Therefore, the real conditions of existence require from business entities sound decisionmaking related to financial risks and support of a comprehensive regulatory framework for regulating their management. 


\subsection{Management of financial risks in the stages of the life cycle of the enterprise}

Each stage in the life cycle of an industrial enterprise has certain causes of the risks and must have effective measures to minimize or overcome them. However, there are risks that accompany the company at all stages of the life cycle (table). One of them is the risk of quality and incomplete information. This risk is due to uncertainty or asymmetry of information, since in a competitive environment, industrial enterprises have a desire not to disclose all available information. This leads to multicriteria and conflict in the assessment of events, when one has to consciously make compromise solutions.

Table 1 Financial risks in the life cycle of the enterprise

\begin{tabular}{|c|c|c|c|c|}
\hline $\begin{array}{l}\text { Stage of Life } \\
\text { Cycle }\end{array}$ & $\begin{array}{l}\text { Probability of } \\
\text { occurrence of } \\
\text { risks }\end{array}$ & $\begin{array}{l}\text { Specific } \\
\text { financial risks }\end{array}$ & $\begin{array}{l}\text { Economic methods of } \\
\text { managing financial risks }\end{array}$ & $\begin{array}{l}\text { Regulatory and } \\
\text { legal support for } \\
\text { financial risk } \\
\text { management }\end{array}$ \\
\hline \multirow{2}{*}{$\begin{array}{l}\text { Access to the } \\
\text { market }\end{array}$} & $\begin{array}{c}\text { Emergence of } \\
\text { threats }\end{array}$ & \multirow{2}{*}{$\begin{array}{l}\text { Investment; } \\
\text { credit; tax; } \\
\text { inflationary }\end{array}$} & $\begin{array}{l}\text { Prevention of threats and } \\
\text { risks: statistical; expert } \\
\text { assessments; analogies; } \\
\text { "tree of solutions"; } \\
\text { insurance, etc. }\end{array}$ & \multirow{10}{*}{$\begin{array}{l}\text { Constitution of } \\
\text { Ukraine } \\
\text { The Commercial } \\
\text { Code (Chapter 4, } \\
\text { Articles 42-51; Part } \\
\text { 1, Article 142) [16] } \\
\text { Art. 8 of the Law of } \\
\text { Ukraine "On } \\
\text { Employment of the } \\
\text { population" [5] } \\
\text { Art. 17 of the Law } \\
\text { of Ukraine } \\
\text { "On the basis of } \\
\text { social protection of } \\
\text { the disabled in } \\
\text { Ukraine" [8] } \\
\text { Art. 1 of the Law of } \\
\text { Ukraine "On the } \\
\text { Procedure for } \\
\text { Settlements in } \\
\text { Foreign Currency" } \\
\text { [9] } \\
\text { Civil Code [11] } \\
\text { "On Fundamentals } \\
\text { of National } \\
\text { Security of } \\
\text { Ukraine" [7], "On } \\
\text { Protection of } \\
\text { Economic } \\
\text { Competition" [6] } \\
\text { financial and legal } \\
\text { regulation of legal } \\
\text { relations }\end{array}$} \\
\hline & $\begin{array}{l}\text { The onset of a } \\
\text { risky situation }\end{array}$ & & $\begin{array}{l}\text { Risk Remedy: Sensitivity } \\
\text { analysis; script analysis; } \\
\text { "Tree of failure"; } \\
\text { expediency; utility } \\
\text { function, etc. }\end{array}$ & \\
\hline \multirow{2}{*}{$\begin{array}{l}\text { Growth } \\
\text { (expansion of } \\
\text { activity) }\end{array}$} & $\begin{array}{c}\text { Emergence of } \\
\text { threats }\end{array}$ & \multirow{6}{*}{$\begin{array}{l}\text { Percentage } \\
\text { monetary; } \\
\text { credit; loss of } \\
\text { solvency; } \\
\text { reduction of } \\
\text { financial } \\
\text { stability; } \\
\text { innovative; tax; } \\
\text { inflationary }\end{array}$} & $\begin{array}{l}\text { Prevention of threats and } \\
\text { risks: analytical; "tree of } \\
\text { solutions"; game theory }\end{array}$ & \\
\hline & $\begin{array}{l}\text { The onset of a } \\
\text { risky situation }\end{array}$ & & $\begin{array}{l}\text { Elimination of risks: "tree } \\
\text { of failures"; securitization; } \\
\text { insurance, etc. }\end{array}$ & \\
\hline \multirow[b]{2}{*}{ Maturity } & $\underset{\text { threats }}{\text { Emergence of }}$ & & $\begin{array}{l}\text { Prevention of threats and } \\
\text { risks: analytical; "tree of } \\
\text { solutions"; game theory }\end{array}$ & \\
\hline & $\begin{array}{l}\text { The onset of a } \\
\text { risky situation }\end{array}$ & & $\begin{array}{l}\text { Risk Remedy: Kornai } \\
\text { Software Modeling; } \\
\text { marketing matrices; scoring } \\
\text { programs }\end{array}$ & \\
\hline \multirow[t]{2}{*}{ Saturation } & $\begin{array}{l}\text { Emergence of } \\
\text { threats }\end{array}$ & & $\begin{array}{l}\text { Prevention of Threats and } \\
\text { Risks: Simulation of Monte } \\
\text { Carlo; marketing matrices, } \\
\text { etc. }\end{array}$ & \\
\hline & $\begin{array}{l}\text { The onset of a } \\
\text { risky situation }\end{array}$ & & $\begin{array}{l}\text { Elimination of risks: "tree } \\
\text { of failures"; insurance }\end{array}$ & \\
\hline \multirow{2}{*}{$\begin{array}{l}\text { Leaving the } \\
\text { market }\end{array}$} & $\begin{array}{l}\text { Emergence of } \\
\text { threats }\end{array}$ & \multirow{2}{*}{$\begin{array}{l}\text { Investment; tax; } \\
\text { credit; loss of } \\
\text { solvency; } \\
\text { reduction of } \\
\text { financial } \\
\text { stability; price }\end{array}$} & $\begin{array}{l}\text { Prevention of Threats and } \\
\text { Risks: Risk Map; } \\
\text { analogies; game theory }\end{array}$ & \\
\hline & $\begin{array}{l}\text { The onset of a } \\
\text { risky situation }\end{array}$ & & $\begin{array}{l}\text { Elimination of risks: "tree } \\
\text { of failures"; insurance }\end{array}$ & \\
\hline
\end{tabular}

Along with the generally accepted types of threats and risks of an enterprise, there are some and specific ones. The main specific types of systematic (market) financial risks at the stage of entry of the company into the market can be attributed:

- investment risk, characterized by the possibility of financial losses in the process of investment activity of the enterprise;

- the credit risk that occurs in the financial activity of the enterprise in providing it with a commodity loan to buyers for further establishment of relations with them; 
- tax risk arises as a result of changes in legislative acts regarding the probability of introducing new taxes and fees, changes in the procedure for charging and timing of payment of existing obligatory payments, cancellation of tax benefits, etc .;

- inflationary risk is characterized by the ability to depreciate the real value of capital and reduce revenues from the results of financial activity of the enterprise in the conditions of inflation.

At the stages of growth, maturity, saturation, there may be specific financial risks such as:

- interest rate risk arises as a result of an unexpected change in the interest rate on the financial market;

- currency risk arises in the course of foreign economic activity as a result of changes in the exchange rate of foreign currency;

- the risk of reducing the structure of capital, which leads to imbalances in the volume of positive and negative cash flows of the enterprise;

- the risk of insolvency of an enterprise is characterized by a decrease in the level of liquidity of circulating assets;

- innovative risk associated with the introduction of new financial technologies, the use of new financial instruments, etc.

Possessing reliable information about the legal relationship between different market players, it is possible to predict more or less probable threats and risks. Estimation of the probability of occurrence of risk is possible with the use of qualitative and quantitative methods and techniques, and depending on the stage of the life cycle of the enterprise, they may differ. Considering that the company's financial risk is an indicator of complexity that combines a large number of external and internal factors, or simple risks [1, 13], we propose a model for an integrated assessment of a company's financial risk in the enterprise security system.

First of all, it is necessary to determine the frequency of occurrence of some level of losses:

$p=n / n_{z g}$

where $p$ is the frequency of occurrence of some level of losses;

$p$ - number of cases of occurrence of a specific level of losses;

$p_{z g}$ - the total number of cases in the statistical sample, which covers all, in that account, and successfully carried out operations.

It is expedient to determine the degree of risk in absolute terms for the characteristics of certain types of losses, and for relative - when comparing the projected level of losses with real, medium-sized, average in the market segment, etc.

In absolute terms, the degree of risk (the measure of expected failure in achieving the goal) can be defined as the product of the probability of failure (undesirable consequences) by the magnitude of these undesirable effects (losses, payments, etc.) [1]:

$R j=B j \times p j$

where $R j$ is the magnitude of the risk;

$B j$ is amount of losses (losses);

pj is probability of unwanted risks.

The probability ( $p$ ) with a sufficient degree of accuracy is calculated on the basis of statistical data. To evaluate the actual data, all probabilities take the same and are determined as follows:

$$
P=1 / n
$$

The average expected value is associated with the uncertainty of the situation, it is expressed in the form of the weighted average of all possible results where the probability of each result $(\mathrm{p})$ is used as the frequency or weight of the corresponding value (B).

Then, hopefully, the most probable value of losses (losses, income, profit) - will be: 


$$
B_{u}=\sum_{i=1}^{n} B_{i} \times p_{i}
$$

where $\mathrm{n}$ - number of cases;

$B_{i}$ - the magnitude of losses (losses, income, profit) in the second case;

$p_{i}$-is the probability of occurrence of the th case.

The average expected value is a generalized quantitative characteristic and does not allow a decision to be made in favor of any option. For the final decision it is necessary to measure the fluctuations of the indicators, that is, to determine the extent of the fluctuations of the possible result. Fluctuations of the possible result are the degree of deviation of the expected value from the mean value. For its determination, usually the variance is calculated, or the mean square deviation.

The dispersion is the weighted average of the squares of deviations of actual results from the mean value:

$$
\sigma^{2}=\sum_{i=1}^{n}\left(B_{i}-B_{u}\right)^{2} \times p_{i}
$$

The mean square deviation is calculated by performing statistical tests of various hypotheses, as well as for identifying the relationships between random variables. This statistic is the most common type of deviations used in calculating quantitative risk indicators and is determined by the formula:

$$
\sigma=\sqrt{\sigma^{2}}=\sqrt{\sum_{i=1}^{n}\left(B_{i}-B_{u}\right) \times p_{i}}
$$

The coefficient of variation $(\mathrm{g})$ that allows you to compare the fluctuations of the signs having different units of measurement. The higher the coefficient of variation, the stronger the oscillation of the sign.

$$
r=\sigma / B_{u}
$$

Based on the results of calculating the value of the coefficient of variation, the following scale can be used to assess financial risk:

0,0-0,1 - minimal risk;

$0,1-0,25$ - low risk;

$0,25-0,50$ - acceptable risk;

$0,50-0,75$ - critical risk;

$0,75-1,0$ - catastrophic risk.

Thus, real business conditions require industry to make informed decisions about financial risks. Therefore, before taking a managerial decision regarding the further development of the enterprise, it is necessary to establish which risk the group, type and type will have to deal with, as well as quantify the degree of potential hazard from the occurrence of a risk event.

\section{References}

1.V.V. Vitlinskyi, H.I. Velykoivanenko, Rizikologsya v ekonomitsi ta pidpriemnitstvi: monogr, Kiyv, 480 (2004).

2. Zakon Ukrayini «Pro strahuvannya» [Tekst] : za stanom na 10 bereznya 2005 roku / Verhovna Rada Ukrayini. - Ofitsiyne vidavnitstvo. - K. : Parlamentske vidavnitstvo, 2005. - 42 s. (SerIya «Zakoni Ukrayini»). - ISBN 966-611-356-2.

3. Pro banki $i$ bankivsku diyalnist (iz zminami ta dopovnennyami): Zakon Ukrayini vid 07.12.2000 №2121 - III. [Elektronniy resurs], rezhim dostupu http://zakon2.rada.gov.ua/laws/show/2121-14

4. Pro zaynyatist naselennya : zakon Ukrayini vid 1 berez. $1991 \mathrm{r}$ № 803-XII // Vidomosti Verhovnoyi Radi URSR. - 1991. - №14. - st. 170.

5. Pro zahist ekonomichnoyi konkurentsiyi : zakon Ukrayini vid 11 sIch. 2001 r. №2210-III // Vidomosti Verhovnoyi Radi Ukrayini. - 2001. - №12. - st. 64.

6. Pro osnovi natsIonalnoyi bezpeki Ukrayini: zakon Ukrayini vid 19 cherv. 2003 r. №964-IV // Vidomosti Verhovnoyi Radi Ukrayini. - 2003. - № 39. - st. 351.

7. Pro osnovi sotsialnoyi zahischenosti invalidiv v Ukrayini : zakon Ukrayini vid 21 berez. 1991 r. №875-XII // Vidomosti Verhovnoyi Radi URSR. - 1991. - № 21. - st. 252. 
8. Pro poryadok zdiysnennya rozrahunkiv $v$ inozemniy valyuti : zakon Ukrayini vid 23 veres. 1994 r. № 185/94-VR // VIdomostI Verhovnoyi Radi Ukrayini. - 1994. - №40. - st. 364.

9. K.D. Semenova, Riziki dIyalnostI promislovih pidpriemstv: integralne otsinyuvannya. Monografiya, Odesa, 234 (2017).

10. Tsivilniy kodeks Ukrayini : zakon Ukrayini vid 16 sich. 2003 r. №435-IV // Vidomosti Verhovnoyi Radi Ukrayini. - 2003. - №40. - st. 356.

11. Yu.H. Kim, Finansovi ryzyky v systemi finansovo-ekonomichnoi bezpeky pidpryiemstva, Finance of Ukraine, 6, 13-18 (2005).

12. V.V. Vitlinskyi, Kontseptualni zasady ryzykolohii u finansovii diialnosti. Finance of Ukraine, 3, 4-9 (2003).

13. V.Z. Kuzminskyi, O. Chynarov, Finansovi ryzyky subiektiv hospodariuvannia. Mizhnarodnyi naukovyi zhurnal «Internauka», 2 (24), 2 t., 97-101 (2017).

14. A. Kovalchuk, Finansove pravo: problemy utverdzhennia ta efektyvnoho zastosuvannia, Publichne pravo, 1 (25), 10-17 (2017).

15. V.V. Kovalenko, Finansovi ryzyky ta shliakhy yikh minimizatsii (pravovyi aspekt), Kyiv, 319 (2011).

16. Gospodarskiy kodeks Ukrayini vid 16.01.2003 № 436-15, (2003): http://zakon4.rada.gov.ua/laws/show/436-15 . - Nazva z ekranu. 